\title{
AXONAL DEGENERATION IN ASSOCIATION WITH CARPAL TUNNEL SYNDROME
}

\author{
Marcelo Ribeiro Caetano ${ }^{1}$
}

\begin{abstract}
Median nerve entrapment in the palm to wrist segment is known as carpal tunnel syndrome (CTS). Electromyography is the best evaluation test to confirm the disease, as it shows a median reduced conduction velocity and/or conduction block; however, the usual CTS electrodiagnostic tests do not separate segmental demyelination alone from segmental demyelination plus secondary axonal degeneration. We studied 100 hands from CTS patients (classified as mild, moderate, and severe), and 50 hands from normal subjects. The median palmar sensory nerve action potential (SNAP) amplitude was measured and compared between the two groups. It would be expected that SNAP was normal if no axonal degeneration had occurred. The results showed that in mild CTS group and part of moderate CTS group SNAP amplitude was normal, whereas in severe CTS group, and part of moderate group SNAP amplitude was reduced, proving that axonal degeneration was involved. As it is well stated that axonal lesions have worse prognosis than segmental demyelinating ones, this simple test may help to preditic the CTS outcome and treatment.
\end{abstract}

KEY WORDS: carpal, tunnel, syndrome, axonal, degeneration.

\section{Degeneração axonal na síndrome do túnel do carpo}

RESUMO - A compressão do nervo mediano no segmento punho-palma produz uma entidade clínica conhecida como síndrome do túnel do carpo (STC). A eletroneuromiografia é o exame de escolha para o diagnóstico da STC, através da identificação de diminuição de velocidade e/ou bloqueio de condução quando estudamos a neurocondução do nervo mediano, no trecho do punho. Entretanto, as técnicas comumente usadas não conseguem separar a lesão em mielínica focal com ou sem degeneração axonal secundária. Avaliamos 100 mãos de pacientes com STC e comparamos com 50 mãos de um grupo controle. Medimos a amplitude do potencial de ação do nervo sensitivo do mediano, com estímulo na palma e captação no dedo, e comparamos entre os grupos controle e de pacientes (o grupo de STC foi subdividido em leve, moderado e grave). Era esperado que a amplitude do potencial estivesse normal enquanto não houvesse degeneração axonal secundária. Os resultados mostraram que, no grupo de STC leve e parte do grupo de STC moderado, a amplitude do potencial está normal, enquanto que, no grupo de STC grave e em parte do grupo de STC moderado, a amplitude está diminuída, ou o potencial está abolido, demonstrando que existe degeneração axonal secundária nos casos de STC mais graves. Como em geral as lesões mielínicas focais têm melhor prognóstico do que as axonais, concluímos que a avaliação proposta pode ser útil no prognóstico e na orientação terapêutica.

PALAVRAS-CHAVE: síndrome, túnel, carpo, degeneração axonal.

Median nerve entrapment in the wrist to palm segment produces a clinical condition known as carpal tunnel syndrome (CTS), the most common entrapment neuropathy' ${ }^{1}$. In compressive neuropathies the severity and duration of nerve compression produces various degrees of demyelination and in some cases axonal degeneration, which can be determined by comparing responses evoked proximal and distal to the lesion site ${ }^{2}$. However, the most common CTS electrodiagnostic tests do not use distal stimulation, with distal record ${ }^{3}$. In CTS both axonal degeneration and conduction block can cause weakness, impaired voluntary recruitment of motor units, and low amplitude (even absent) compound action muscular potential (CMAP) as well as sensory nerve action potential (SNAP). Conduction block can only be distinguished from axonal degeneration by comparing the amplitude and duration of responses from palmar and wrist stimulation, with distal recording ${ }^{4}$.

In this prospective study we investigated segmental sensory conduction and compared the wrist and palm SNAP, in order to determine the frequency of

Serviço de Neurofisiologia do Labs - Rio de Janeiro RJ, Brasil: ${ }^{1}$ Médico especialista em eletroneuromiografia pela Sociedade Brasileira de Neurofisiologia Clínica-Associação Médica Brasileira.

Received 25 June 2002, received in final form 9 September 2002. Accepted 17 September 2002. 
axonal degeneration. We used only sensory conduction as it is generally stated that motor conduction testing is less sensitive than sensory testing in $\mathrm{CTS}^{1,3,5,6}$ because of the number of pitfalls and technical problems with palm motor stimulation. In order to classify and graduate CTS, we used a modified neurophysiologic grading scale proposed by Stevens ${ }^{1}$, with wrist stimulation. Our scale is as follows: mild CTS: SNAP with delayed latency and normal CMAP; moderate CTS: SNAP and CMAP with delayed latencies, or abolished SNAP and CMAP with distal latency lower than $6.6 \mathrm{~ms}$; severe CTS: abolished SNAP and CMAP, or abolished SNAP and CMAP with distal latency upper than $6.5 \mathrm{~ms}$.

\section{METHOD}

Control values were obtained from fifty hands of 30 patients referred to our EMG laboratory, with low back pain and/or lower limbs complains, who did not have typical symptoms and signs of CTS $^{7}$, or other peripheral neurological disorders in the upper limbs, aged between 20 and 80 years (mean 40.7 years), $88 \%$ women. We studied one hundred hands of 61 consecutive patients $(91 \%$ women) aged between 22 and 79 years (mean 47.6 years), that had CTS symptoms and SNAP wrist latency upper than $3.5 \mathrm{~ms}$ (peak-measured).

All studies were performed by the same physician, on a LBM- 4E (Bio-logics, Neuro Diagnostic Inc., Mundelein, Illinois, USA) electromyography machine. The palm temperature (skin) was monitored during the exams and, if below 32 grades centigrade, the extremity was warmed. The SNAP was averaged when necessary. The filter band pass was $5 \mathrm{~Hz}$ to $5 \mathrm{kHz}$ for motor studies and $30 \mathrm{~Hz}$ to $3 \mathrm{kHz}$ for sensory studies. The gain was $10 \mathrm{uV} /$ div for sensory studies and $2 \mathrm{mV}$ for motor studies. The sweep speed was $1 \mathrm{~ms} /$ div for sensory studies and $2 \mathrm{~ms} /$ div for motor studies. The CMAP was recorded with surface electrodes from the abductor pollicis brevis (APB) (G1) and its tendon just distal to the metacarpophalangeal joint (G2), and the SNAP was recorded with a ring electrode on the proximal interphalangeal joint (G1) and on the distal interphalangeal joint (G2) of the third digit. The median nerve was stimulated at the palm and wrist with a hand held stimulator with inter electrode distance of $2 \mathrm{~cm}$. The wrist stimulation site was located $8 \mathrm{~cm}$ proximal to the APB record (motor), and $14 \mathrm{~cm}$ proximal to the third digit record (sensory). A stimulus was considered supramaximal if there were no change in amplitude and latency of the CMAP and SNAP, despite increasing stimulus intensity. Amplitude of negative peak of CMAP was measured, as far as the peak-to-peak amplitude of SNAP. A $3 \mathrm{~cm}$-ground was placed on the palm, between the stimulus and record site. Ulnar motor and sensory, and radial sensory nerve conduction, as well as needle EMG in the pronator teres, triceps, deltoideus, and first dorsal interossei of the hand was performed in order to exclude other disorders.

Descriptive statistics, including the mean and standard deviation were applied to each median conduction value, and lower or upper limits of normality of controls were calculated by rounding the mean \pm 2.5 standard deviations.

\section{RESULTS}

Table 1 summarizes the results of the median nerve conduction in controls and CTS patients. With palm stimulation the mean sensory peak latency (SPL) was $1.75 \mathrm{~ms}$ in the control group, $1.91 \mathrm{~ms}$ in the mild CTS group, $2.06 \mathrm{~ms}$ in the moderate CTS group, while in the severe CTS group it was 2.56 ms. Mean palmar SNAP amplitude was $90.5 \mathbf{u V}$ in the control group, $55.2 \mathrm{uV}$ in the mild CTS group, $41.5 \mathrm{uV}$ in the moderate CTS group, while in the severe CTS group it was $7.3 \mathrm{uV}$ (much smaller than controls, $\mathrm{P}<0.0001, t$-test). With wrist simulation the mean SPL was $3.03 \mathrm{~ms}$ in the control group, $3.81 \mathrm{~ms}$ in the mild CTS group, $4.62 \mathrm{~ms}$ in the moderate CTS group, and in the severe CTS group SNAP was not obtained. Mean wrist SNAP amplitude was $68.0 \mathrm{uV}$ in the control group, $41.4 \mathrm{uV}$ in the mild CTS group, $27.3 \mathrm{uV}$ in the moderate CTS group, and in the severe CTS group SNAP was not obtained. In the control group the mean palm/wrist SNAP amplitude ratio was 1.35 , in the mild CTS group it was 1.33 , and in

Table 1. Sensory conduction values in controls and CTS.

\begin{tabular}{lcccccc}
\hline & Hands(n) & $\begin{array}{c}\text { SPL } \\
(7 \mathrm{~cm}) \mathrm{ms}\end{array}$ & $\begin{array}{c}\text { SNAP amp } \\
(7 \mathrm{~cm}) \mathbf{u V}\end{array}$ & $\begin{array}{c}\text { SPL } \\
(14 \mathrm{~cm}) \mathrm{ms}\end{array}$ & $\begin{array}{c}\text { SNAP amp } \\
(14 \mathrm{~cm}) \mathbf{u V}\end{array}$ & $\begin{array}{c}\text { SNAP amp } \\
7 \mathrm{~cm} / 14 \mathrm{~cm}\end{array}$ \\
\hline Controls & 50 & $\begin{array}{c}1.75 \pm 0.15 \\
(2.12)^{*}\end{array}$ & $\begin{array}{c}90.5 \pm 23.1 \\
(32.7)^{* *}\end{array}$ & $\begin{array}{c}3.03 \pm 0.22 \\
(3.58)^{*}\end{array}$ & $\begin{array}{c}68.0 \pm 18.5 \\
(21.75)^{* *}\end{array}$ & $\begin{array}{c}1.33 \\
(1.50)\end{array}$ \\
Mild CTS & 10 & $1.91 \pm 0.07$ & $55.2 \pm 11.7$ & $3.81 \pm 0.22$ & $41.4 \pm 9.8$ & 1.33 \\
Moderate CTS & 77 & $2.06 \pm 0,27$ & $41.5 \pm 23,7$ & $4.62 \pm 1.11$ & $27.3 \pm 18.4$ & 1.52 \\
Severe CTS & 13 & $2.56 \pm 0.33$ & $7.3 \pm 3.4$ & 0 & 0 & \\
\hline
\end{tabular}

SPL, sensory peak latency; SNAP amp, SNAP amplitude; *ULN, upper limit of normality; **LLN, lower limit of normality. 
Table 2. Cts group x snap amplitude $-7 \mathrm{~cm}$.

\begin{tabular}{lcc}
\hline & Norma SNAP-7cm* & Abnormal SNAP-7 $\mathrm{cm}^{* *}$ \\
\hline Mild CTS & 10 hands (100\%) & 0 hands $(0 \%)$ \\
Moderate CTS & 31 hands $(40,3 \%)$ & 46 hands $(59,7 \%)$ \\
Severe CTS & 0 hands $(0 \%)$ & 13 hands $(100 \%)$ \\
\hline *amplitude upper than 36.6 uV **amplitude lower than 36.7 uV or absent SNAP
\end{tabular}

the moderate CTS group it was 1.52. In the severe CTS group it was not possible to calculate it because the SNAP was abolished with wrist stimulation.

Table 2 summarizes the results of the CTS group, in relation with the SNAP amplitude with palm stimulation. The mild CTS group had $100 \%$ of the 10 hands with normal SNAP amplitude, while the severe CTS group had $100 \%$ of the 13 hands with abnormal SNAP amplitude. The intermediate group (moderate CTS) had 46 hands (59.7\%) with abnormal SNAP amplitude, and 31 hands (40.3\%) had normal SNAP amplitude.

\section{DISCUSSION}

In CTS, employing only standard determination of median distal latency (MDL) to APB and sensory conduction (wrist stimuli), it is impossible to distinguish how much of a reduced CMAP or SNAP is due to axonal degeneration, and how much is due to focal demyelination. According to Johnson ${ }^{4}$ prominent conduction block suggests a conservative treatment such as splitting or steroid injections, whereas prominent axonal loss is well-accepted indication for surgery. Despite the great controversial of this theme, it is well stated that demyelinating lesions have better prognosis than axonal ones.

Di Guglielmo et al. ${ }^{8}$, Lesser et al. ${ }^{2}$ and Pease et al. ${ }^{9}$ have published distinct works where they used palmar stimulation in CTS, in order to study the conduction block beneath the carpal tunnel segment, but they have given little importance to axonal degeneration. Warfel et al. ${ }^{10}$ have been the first who used the median palmar SNAP amplitude in order to predict the surgical outcome in CTS, and found that it is a good index, while latencies are not.

In our series $100 \%$ of mild CTS hands had a normal palmar SNAP amplitude (upper than mean control-2.5 SD), in contrast with severe CTS hands, which had $100 \%$ with low amplitude or absent SNAP, indicating that the mild CTS group had only segmental demyelinating injury, whereas the severe CTS group had a combined axonal and demyelinating injury. With this knowledge we may treat mild and part of moderate CTS patients with conservative treatment, as there are only focal demyelination, without secondary axonal degeneration.

\section{CONCLUSION}

In CTS, as in other compressive neuropathies, it is possible to distinguish between the relative quota of conduction block and axonal degeneration in sensory and motor fibers, stimulating distal to the entrapment site. This simple test may be useful in establishing prognosis and addressing treatment, as it is well stated that axonal lesions have worse prognostic than segmental demyelinating ones, but further studies are necessary to confirm this.

\section{REFERENCES}

1. Stevens JC. The electrodiagnosis of carpal tunnel syndrome: Muscle Nerve 1987;20:1477-1486.

2. Lesser EA, Venkatesh S, Preston DC, Logigian EL. Stimulation distal to the lesion in patients with carpal tunnel syndrome. Muscle Nerve 1995;18:503-507.

3. Kimura J. The carpal tunnel syndrome: localization of conduction abnormalities within the distal segment of the median nerve. Brain 1979;102:619-635.

4. Johnson EW. Should immediate surgery be done for carpal tunnel syndrome? No! Muscle Nerve 1995;18:658-659.

5. American Association of Electrodiagnostic Medicine Quality Assurance Committee. Literature review of usefulness of nerve conduction studies and electromyography for the evaluation of patients with carpal tunnel syndrome. Muscle Nerve 1993:1392-1414.

6. Olney RK, Miller RG. Conduction block in compression neuropathy: recognition and quantification. Muscle Nerve 1984;7:662-667.

7. American Academy of Neurology Quality Standards Subcommittee Practice Parameters: carpal tunnel syndrome (summary statement). Neurology 1993;43:2406-2409.

8. Di Guglielmo G, Torrieri F, Repaci M, Uncini T. Conduction block and segmental velocities in carpal tunnel syndrome. Electroencephalogr Clin Neurophysiol 1997;105:321-327.

9. Pease WS, Cinningham ML, Walsh WE, Johnson EW: Determining neuropraxia in carpal tunnel syndrome. Am J Phys Med Rehabil 1988;3:117-119.

10. Warfel BS, Agha A, Tranchitella VJ. Predicting surgical outcome of severe carpal tunnel syndrome with nerve conduction studies. Muscle Nerve 2001;24:1416-1417. 